\title{
Stem Cell-Derived Culture Models of Hepatitis E Virus Infection
}

\author{
Viet Loan Dao Thi, Xianfang Wu, and Charles M. Rice \\ Laboratory of Virology and Infectious Diseases, The Rockefeller University, New York, New York 10065 \\ Correspondence: vdaothi@rockefeller.edu; xwu02@rockefeller.edu; ricec@mail.rockefeller.edu
}

Similar to other hepatotropic viruses, hepatitis E virus (HEV) has been notoriously difficult to propagate in cell culture, limiting studies to unravel its biology. Recently, major advances have been made by passaging primary HEV isolates and selecting variants that replicate efficiently in carcinoma cells. These adaptations, however, can alter HEV biology. We have explored human embryonic or induced pluripotent stem cell (hESC/iPSC)-derived hepatocyte-like cells (HLCs) as an alternative to conventional hepatoma and hepatocyte cell culture systems for HEV studies. HLCs are permissive for nonadapted HEV isolate genotypes (gt)1-4 replication and can be readily genetically manipulated. HLCs, therefore, enable studies of pan-genotype HEV biology and will serve as a platform for testing anti-HEV treatments. Finally, we discuss how hepatocyte polarity is likely an important factor in the maturation and spread of infectious HEV particles.

\begin{abstract}
Compared with the other hepatotropic virusCes, hepatitis E virus (HEV) infections show dramatic heterogeneity and little is known about the underlying viral or host determinants that affect disease severity and outcome. Four major genotypes (gt), 1-4, can infect humans. gt1 and gt2 are transmitted fecal-orally and lead to large outbreaks in developing countries. In gt1- and gt2-endemic areas, most infections and illness occur in young healthy individuals, with high fatality rates in pregnant women. gt 3 and gt 4 infect animals and can be transmitted to humans zoonotically through the ingestion of infected meat. These genotypes can cause acute or chronic infections in the developing and developed world, with middle-aged to elderly males the most likely to experience severe disease (reviewed in Hartl et al. 2016). A single case study
\end{abstract}

suggests that camelid HEV gt7 may also be zoonotic and transmitted to humans (Lee et al. 2016). Of the human hepatitis viruses, HEV is the only one in which animal reservoirs can seed human infections. HEV infections primarily cause hepatitis but can also feature extrahepatic disorders, such as neurological syndromes, renal injury, pancreatitis, and hematological problems (Kamar et al. 2014). This parallels observations in HEV-infected animals in which replicative RNA intermediates are found in numerous organs such as lymph node, colon, small intestine, brain, and spleen (Williams et al. 2001; Liu et al. 2013), and in cell culture in which different lung, intestinal, and neuronal tissue cell lines are permissive for HEV infection (reviewed in Okamoto 2011). To date, the determinants of species and tissue tropism of HEV are unknown.

Editors: Stanley M. Lemon and Christopher Walker

Additional Perspectives on Enteric Hepatitis Viruses available at www.perspectivesinmedicine.org

Copyright (C) 2019 Cold Spring Harbor Laboratory Press; all rights reserved; doi: 10.1101/cshperspect.a031799

Cite this article as Cold Spring Harb Perspect Med 2019;9:a031799 
V.L. Dao Thi et al.

Similar to other hepatotropic viruses, HEV is notoriously difficult to propagate in conventional cell cultures. Although this has limited studies of its biology in the past, recent advances in cell culture systems, including in particular the use of human embryonic or induced pluripotent stem cell (hESC/iPSC)-derived hepatocyte-like cells (HLCs), offer substantial promise for unraveling how HEV interacts with and replicates within the hepatocyte.

\section{HETEROLOGOUS EXPRESSION SYSTEMS FOR THE STUDY OF HEV}

HEV has a 7.2-kb, positive-strand RNA genome that harbors three partially overlapping open reading frames (ORFs). ORF1 encodes all the functions required for viral RNA replication and is encoded by the full-length genome RNA (Agrawal et al. 2001; Magden et al. 2001; Karpe and Lole 2010). In addition, viral replication leads to the generation of a shorter, subgenomic RNA of $2.2 \mathrm{~kb}$ that encodes the capsid protein, ORF2 (Surjit et al. 2004; Xing et al. 2010), and the small phosphoprotein, ORF3, which is involved in virus secretion (Yamada et al. 2009; Nagashima et al. 2011; Ding et al. 2017). Recently, a novel ORF (ORF4) was identified within the ORF1 sequence, which is largely conserved among gt1 isolates (Nair et al. 2016; also see Kenney and Meng 2018).

As discussed in the next paragraph, HEV replication systems for studies in cell culture have been developed only recently. Before that, a range of different heterologous expression systems was used to study the HEV proteins and life cycle in cell culture, with disparate results. For example, HEV ORF1 has been expressed in Escherichia coli, insect, or mammalian cells using a variety of different systems, including vaccinia virus-, baculovirus- and T7-, CMV-, or SV40driven plasmid expression. In these studies, the ORF1 translation product was either found nonprocessed as a large $185 \mathrm{kDa}$ polyprotein or processed with varying cleavage products, depending on the system used (Ansari et al. 2000; Ropp et al. 2000; Suppiah et al. 2011; Perttila et al. 2013). Likewise, the predicted HEV ORF2 product contains three putative $N$-glycosylation sites and a putative signal peptide at its carboxyl terminus. Yet, reports describing its glycosylation status, and the importance of these features of ORF2 during infectious particle formation using different mammalian expression systems, are inconsistent (Jameel et al. 1996; Torresi et al. 1999; Zafrullah et al. 1999; Surjit et al. 2007; Graff et al. 2008; de Oya et al. 2012). Further, protein interaction studies with ORF2 and ORF3 are largely based on yeast two-hybrid systems (Tyagi et al. 2001; Roy et al. 2004; Osterman et al. 2015; Tian et al. 2017). Altogether, the description of basic steps of the HEV life cycle in authentic replication systems and relevant cell culture models is missing.

\section{CELL CULTURE ADAPTATIONS ENABLING MOLECULAR STUDIES OF HEV BIOLOGY IN CARCINOMA CELLS}

Only recently, major advances have been made by passaging primary gt 3 and gt $4 \mathrm{HEV}$ isolates in human hepatoma cells and selecting for variants that replicate efficiently in culture. These cell culture-adapted variants have enabled studies of the entire HEV life cycle and triggered a wealth of new molecular studies that have advanced knowledge on HEV entry (Yin et al. 2016), replication (Emerson et al. 2013; Zhou et al. 2014; Kenney and Meng 2015), assembly (Kenney et al. 2015; Ding et al. 2017), release (Nagashima et al. 2011, 2014; Ding et al. 2017), cellular tropism (Shukla et al. 2011; Nguyen et al. 2014; Drave et al. 2016; Helsen et al. 2016; Zhou et al. 2017), innate immune evasion (Dong et al. 2012; Nan et al. 2014; Todt et al. 2016a; Sooryanarain et al. 2017), and preclinical drug evaluation (Debing et al. 2014; Wang et al. 2014; Zhou et al. 2014; Dao Thi et al. 2016).

$\mathrm{HEV}$ is therefore similar to other human hepatotropic viruses like hepatitis A virus (HAV) and hepatitis $\mathrm{C}$ virus (HCV) that usually require adaptive mutations to replicate efficiently in cell culture (Emerson et al. 1991; Lohmann et al. 2001). However, in contrast to HAV and $\mathrm{HCV}$, the HEV cell culture-adapted variants include not only single base changes (Tanaka et al. 2007, 2009; Okamoto 2011), but also insertions of human messenger RNA (mRNA) 
sequences or portions of the HEV genome (Shukla et al. 2011; Nguyen et al. 2012; Johne et al. 2014; Debing et al. 2016). These inserted sequences appear to confer a replication advantage in hepatoma cells. For example, Emerson and colleagues recently developed an infectious $\mathrm{HEV}$ gt3 Kernow-C1 complementary DNA (cDNA) clone that was derived from a chronically infected $\mathrm{HEV}$ patient and selected after six serial passages (P6) in HepG2/C3A cells (Shukla et al. 2011, 2012). This adapted virus contains multiple point mutations as well as a 58-aminoacid segment of the human S17 ribosomal protein fragment inserted in frame in the ORF1encoded hypervariable region. The early passage (P1) of the Kernow-C1 isolate replicates to only low levels in human hepatoma cells and the recombinant genome is only a minor species (Shu$\mathrm{kla}$ et al. 2012). Insertion of the S17 sequence into the P1 backbone (Shukla et al. 2012) or into the low replicative gt1 Sar55 strain (Nguyen et al. 2014) increases their ability to replicate in hepatoma cells. Conversely, removal of the S17 sequence from the HEV P6 cDNA clone decreases its replicative ability (Shukla et al. 2012).

These rather dramatic alterations of the viral genome likely alter HEV biology. To our knowledge, similar efforts to adapt gt 1 or gt 2 isolates to grow in cell culture have not been successful. Emerson and colleagues (2010) developed an HEV gtl cell culture system that supports the full replication cycle of the Sar55 strain, but, as mentioned above, this system produces only low virus titers. The apparent ability of HEV gt 3 and gt4 to adapt to a new cellular environment through relatively simple genetic changes may be an important factor in the ability of these genotypes to cross species barriers.

\section{IMPROVED HEPATOCELLULAR SYSTEMS TO STUDY NONADAPTED HEV BIOLOGY}

A major concern of hepatotropic virus studies in cell culture is the widespread use of cancer-derived cell lines. There is no question that these cells have been essential for advancing our basic understanding of hepatotropic virus biology. However, because of their dedifferentiated cancerous nature, they do not necessarily recapitu- late the proliferative, metabolic, apoptotic, and innate immune pathways found in primary hepatocytes (PHHs). Thus, important cellular factors and pathways influencing authentic virus infection, RNA replication, and progeny virus release may be missing. Indeed, the identification of such factors has proven instrumental in developing improved hepatitis B virus (HBV) and HCV cell culture systems. For example, ectopic expression of the lipid-binding protein SEC14L2 in hepatoma cells renders them permissive for replication of nonadapted clinical $\mathrm{HCV}$ isolates (Saeed et al. 2015). HBV can only infect human hepatoma cells when the HBV entry receptor sodium taurocholate cotransporting polypeptide (NTCP) was identified and then ectopically expressed (Yan et al. 2012; Ni et al. 2014).

Recently, endoplasmic reticulum (ER) stress was reported to enhance HEV gt1 replication in hepatoma cells by inducing the translation of HEV ORF4 (Nair et al. 2016). However, it is unclear whether ER stress is also relevant in primary cells or whether this is merely a function of metabolically altered cancer cells. It is likely that the use of cell culture systems that more closely mimic hepatocyte biology in vivo will yield more reliable insight into HEV-host biology.

PHHs isolated from adult or fetal livers represent more physiologically relevant HEV cell culture systems. Mature PHHs, as well as human fetal liver cells (HFLCs), support infection of the cell culture-adapted Kernow-C1 P6 strain (Shukla et al. 2012; Wu et al. 2017; Yin et al. 2017). However, donor-to-donor and batch-to-batch variability, limited accessibility, as well as the restricted ability to perform genetic modifications limit the use of $\mathrm{PHH}$ for many research applications. In addition, mature PHHs often dedifferentiate quickly on plating and lose their hepatic phenotype and key functions (Elaut et al. 2006; Khetani and Bhatia 2008). Therefore, the field would benefit from more reliable, reproducible, and renewable hepatocellular systems.

Embryonic stem cells (ESCs) or iPSCs coupled with highly efficient and reproducible differentiation protocols to generate HLCs provide an attractive alternative to both hepatoma cells and PHHs (reviewed in Schwartz et al. 2014). We and others have shown the usefulness of stem 
V.L. Dao Thi et al.

cell-derived culture systems to study HCV (Yoshida et al. 2011; Roelandt et al. 2012; Schwartz et al. 2012; Wu et al. 2012; Carpentier et al. 2014), HBV (Paganelli et al. 2013; Shlomai et al.2014; Kaneko et al.2016; Xia et al.2017), and HEV (Dao Thi et al. 2016; Helsen et al. 2016; Wu et al. 2017). Although HLCs resemble fetal hepatocytes, they recapitulate more hepatic functions than hepatoma cells. For example, unlike hepatoma cells, HLCs support infection of wild-type $\mathrm{HCV}$ (Wu et al. 2012) and, without further genetic manipulation, HBV (Shlomai et al. 2014; Xia et al. 2017). Similarly, we found that HLCs could be infected with natural isolates of $\mathrm{HEV}$ gt1-4 (Fig. 1) (Wu et al. 2017). HLCs, therefore, provide a reproducible and genetically tractable platform to study nonadapted $\mathrm{HEV}$, particularly gt2 for which currently no cell culture system exists. These studies should help understand genotype-specific differences in HEV biology and may provide insights into the mechanism by which cell culture-adaptive mutations act.

In addition, the intrinsic ability of stem cells to give rise to cells of all three germ layers will allow a better understanding of HEV tissue tropism. Helsen et al. (2016) showed that mesodermal and neural progenitor cells do not support $\mathrm{HEV}$ replication but some neuronal cell lines (Drave et al. 2016) and iPSC-derived neurons (Zhou et al. 2017) are permissive. Using stem cells to generate terminally differentiated primary cell mimics of various lineages and challenging these cells with HEV may help define and understand the determinants of HEV tissue tropism.

\section{CELL CULTURE ADAPTATIONS ALTER HEV BIOLOGY}

Using HLCs, we identified striking differences in virus-host biology between primary and cell

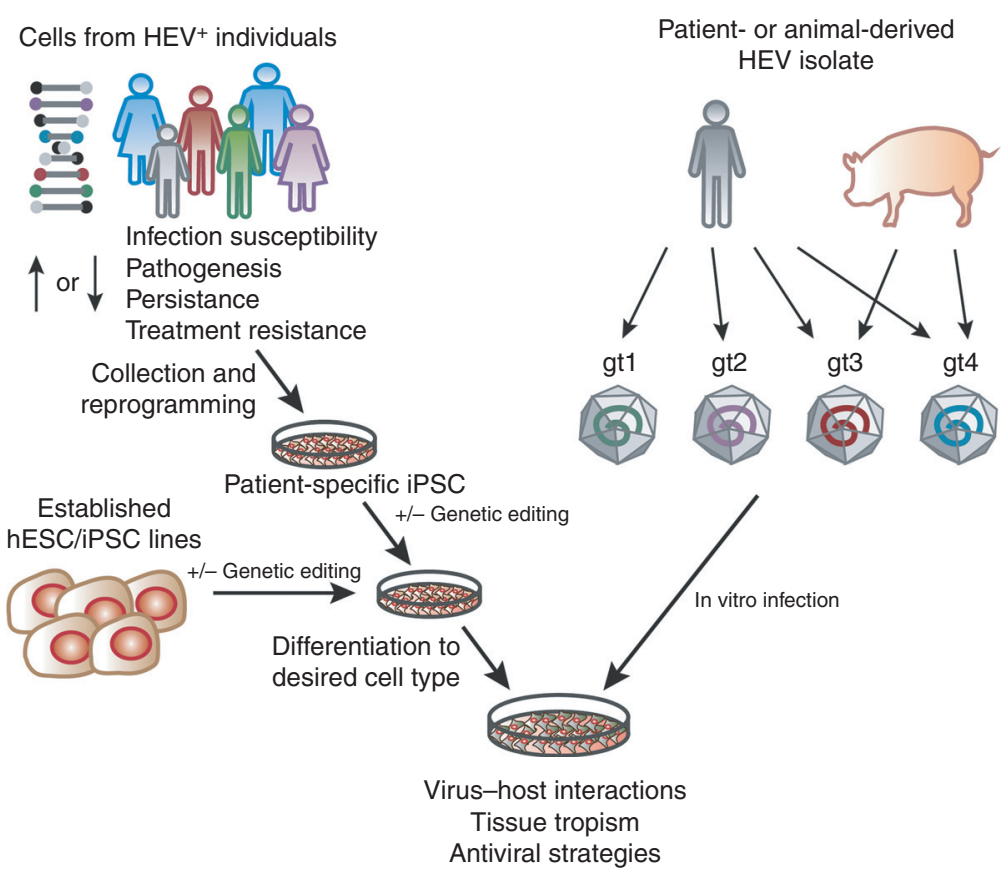

Figure 1. Stem cell culture models of hepatitis E virus (HEV) infection. Cells collected from identified HEVpositive individuals can be reprogrammed to generate induced pluripotent stem cells (iPSCs). Relevant single nucleotide polymorphisms (SNPs) can be repaired or introduced into established human embryonic or induced pluripotent stem cell (hESC)/iPSC lines using CRISPR-Cas9, followed by differentiation to the cell type of interest. Differentiated cells can be directly infected with HEV isolates from patients or animals for modeling virus-host interactions in a dish. 
culture-adapted HEV (Wu et al. 2017). In HLCs, the replication of the cell culture-adapted gt3 Kernow-C1 P6 virus was attenuated compared with its parental P1 virus, indicating that cell culture adaptations may impair virus replication in more physiologically relevant hepatocellular systems. This is similar to what has been described for HAV and HCV, in which cell culture-adaptive, replication-enhancing mutations are deleterious for infection in vivo (Funkhouser et al. 1996; Bukh et al. 2002). We also found that cell culture adaptations can alter host factor dependence ( $\mathrm{Wu}$ et al. 2017). Cyclophilin A (CypA) has been shown to inhibit Kernow-C1 P6 replication in human hepatoma cells (Wang et al. 2014). We confirmed these observations in HLCs. However, when analyzing nonadapted virus, we found that primary isolates as well as the Kernow-C1 P1 virus were not inhibited by CypA nor enhanced by treatment with the calcineurin inhibitor (CNI) cyclosporine A. Other discrepancies are also observed between effects of molecules on HEV replication in vitro and in vivo. Similar to CNIs, mechanistic target of rapamycin (mTOR) inhibitors were reported to promote (Zhou et al. 2014), and mycophenolic acid to inhibit HEV Kernow-C1 P6 replication in vitro (Wang et al. 2014). Yet, in vivo, the time to clear HEV was similar in chronic patients receiving CNIs or mTOR inhibitors, and the use of CNIs or mTOR inhibitors did not influence sustained virologic response rate (SVR) (Kamar et al. 2015). These differences in host factor dependence or drug responsiveness will be important for evaluating future anti-HEV treatments, which can now be validated using cellular systems that allow replication of nonadapted HEV strains, such as HLCs.

A mechanism for the inhibitory role of CypA in cell culture-adapted HEV biology remains to be determined. CypA may interact directly with the $\mathrm{HEV}$ proteins, similar to $\mathrm{HCV}$ nonstructural protein NS5A (Yang et al. 2010) and be modulated by the presence of the S17 sequence. Future studies might compare CypA levels in hepatoma cells to PHHs. An example for HCV is the study by Harak et al. (2017), who found that adaptive mutations were actually loss-of-function mutations preventing phos- phatidylinositol 4-kinase III $\alpha$ overactivation, an enzyme whose expression is high in hepatoma cells compared with PHHs. Moreover, CypA prolyl isomerase activity is a critical positive regulator of RIG-I-mediated innate antiviral immune responses (Liu et al. 2017). Whether the cell culture-adapted strain is better or differentially sensed by the innate immune system would be an interesting subject for future studies. Given their immune competence, HLCs represent an attractive cellular system to study the role of innate immunity in genotype-dependent persistence and/or pathogenesis.

\section{PERSONALIZED HEV MODELS USING STEM CELL TECHNOLOGY}

It is clear that host genetics play a pivotal role in determining susceptibility to infectious diseases. Many virus infection-related Mendelian immune deficiencies inherited as monogenic traits have been uncovered in recent years $(\mathrm{Ca}$ sanova 2015). The ability to generate patientspecific iPSCs (Takahashi et al. 2007) to create personalized cell culture models has the potential to broaden our ability to model these phenotypes in vitro to understand the mechanisms by which they act. The spectrum of genetic polymorphisms and their impact on infectious disease outcome is likely vast and only partially explored.

A striking feature of $\mathrm{HEV}$ infections is their varied and unpredictable outcome, which poses challenges in the clinic. HEV variants found in patients have been described to impact disease pathogenesis, clinical outcome, and antiviral resistance (reviewed in van Tong et al. 2016). For example, drug-resistant, high-fitness variants have been identified in ribavirin-treated chronic HEV patients, leading to treatment failure (Dalton and Kamar 2016; Debing et al. 2016; Todt et al. 2016b). HEV quasispecies diversity is associated with persistent infection and progression to liver fibrosis (Lhomme et al. 2012). Pregnant women in South Asia, but not in high-income countries such as France (Renou et al. 2014), experience more severe disease on $\mathrm{HEV}$ infection, leading to increased maternal and fetal morbidity and mortality (reviewed in 
V.L. Dao Thi et al.

Navaneethan et al. 2008). Nutritional and immunological factors may be important but genetic polymorphisms also may be at play. Future human genetic studies on hepatitis $\mathrm{E}$ patient groups may help reveal whether there is a genetic basis for these dramatic differences.

Known examples are the $\varepsilon 3$ and $\varepsilon 4$ alleles of the apolipoprotein $\mathrm{E}$ gene $(A P O E)$, which are associated with protection against $\mathrm{HEV}$ infection in non-Hispanic blacks (Zhang et al. 2015). ApoE protein is also up-regulated in acutely infected pigs, suggesting a role in HEV infection and/or pathogenesis (Rogee et al. 2015). However, the introduction of APOE isoforms into the human hepatoma cell line Huh7.5 does not affect HEV RNA replication or virus production (Weller et al. 2016). Perhaps different results will unfold in a more physiologically relevant cellular environment. This could be achieved by engineering $A P O E$ polymorphisms into wild-type hESC/iPSCs using CRISPR-Cas9 editing or by generating patient-specific iPSC followed by HLC differentiation and HEV infection (Fig. 1). As iPSCs can be differentiated to many cell types, such studies will not be restricted to characterizing the impact of single nucleotide polymorphisms (SNPs) in HLCs but can be extended to other cell types such as placental or immune cells. The ability to use a patient's own HEV isolate and study its replication without further cell culture adaptation in autologous iPSC-derived HLCs and other cell types will provide a platform for modeling personalized HEV infection, with application not only for understanding HEV-host biology but also evaluating therapeutic options.

\section{HOW DOES CELLULAR POLARITY AFFECT HEV BIOLOGY?}

In the liver, hepatocytes form a cell layer that separates sinusoidal blood from the canalicular bile. This way, hepatocytes are engaged in two counter-current flow systems: On one hand, they take up, process, and secrete the sinusoidal blood components and, on the other hand, synthesize and secrete bile (Musch 2014). To mediate these functions, hepatocytes have a unique polarization with multiple basal membranes facing the sinusoids and multiple apical membranes forming bile canaliculi (Fig. 2A).

Similar to HAV, HEV is an enterically transmitted virus that replicates predominantly in hepatocytes before excretion into feces via bile (Feng et al. 2014). It is assumed that both HEV and HAV enter hepatocytes through their basolateral surface and exit through the apical surface (reviewed in Feng et al. 2014). To support this notion, HEV structural proteins ORF2 and ORF3 are localized at the apical membrane of hepatocytes in chronic HEV patients (Lenggenhager et al. 2017) and infected humanized mice (Allweiss et al. 2016; Sayed et al. 2017). Despite the absence of viral glycoproteins, both viruses acquire a cell host-derived lipid envelope during virus morphogenesis, allowing the virus to bud in a noncytolytic fashion into multivesicular bodies (Emerson et al. 2010; Takahashi et al. 2010; Feng et al. 2013, 2014; Nagashima et al. 2014; Chapuy-Regaud et al. 2017). As a result, cell culture-grown HEV particles released in the cellular supernatant (Nagashima et al. 2011, 2014; Qi et al. 2015; Yin et al. 2016; Chapuy-Regaud et al. 2017) and those circulating in the blood of infected patients (Takahashi et al. 2010) and humanized mice (Allweiss et al. 2016; Sayed et al. 2017) are quasi-enveloped. This envelope decreases cell attachment and thus entry (Yin et al. 2016) but protects the particles from neutralizing antibodies (Takahashi et al. 2010; Chapuy-Regaud et al. 2017) to most likely ensure spread within the infected liver or to other tissues in within the host. In contrast, HEV particles inside infected cells and those excreted into feces are nonenveloped and highly infectious (reviewed in Feng et al. 2014; summarized in Fig. 2), destined to infect the next host. In vitro, treatment with detergent converts quasi-enveloped virions into naked virions (Emerson et al. 2010; Takahashi et al. 2010). In vivo, it is assumed that bile salts of the gastrointestinal tract remove the envelope. However, to date, it remains unknown whether progeny HEV particles bud from the apical membrane as nonenveloped or quasi-enveloped virions.

A subclone of the hepatoma cell line HepG2, when seeded on semipermeable membranes in 


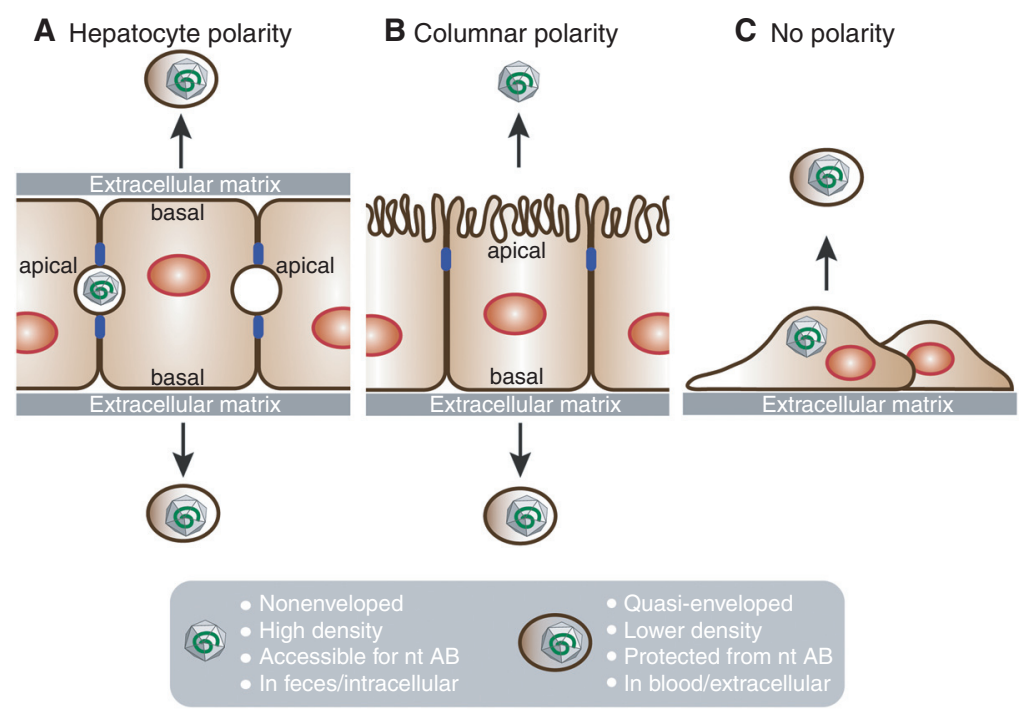

Figure 2. Hepatocyte polarity and hepatitis E virus (HEV) secretion. HEV particle release from hepatocytes with $(A)$ hepatic, $(B)$ columnar, or $(C)$ no polarity. Blue boxes in $A$ and $B$ are tight junctions separating apical and basal membranes.

transwells, acquires an epithelial, columnar type of polarization (Fig. 2B). In this configuration, the cells grow as confluent monolayers and develop tight junctions separating the cell's apical membrane facing the top compartment from the basal membrane facing the bottom compartment of the transwell. This system has been used for HAV (Snooks et al. 2008; Hirai-Yuki et al. 2016), HBV (Bhat et al. 2011), and HCV (Belouzard et al. 2017) entry, secretion, and release studies. HAV release from polarized HepG2 cells is vectorial, with a majority of the virus particles released from the basolateral membrane (Hirai-Yuki et al. 2016). This is in contrast to intestinal, polarized Caco-2 cells, from which HAV buds mainly from the apical membrane (Blank et al. 2000). Whether released from the apical or basolateral side, HAV always exits the cells as enveloped virions, which can be converted into nonenveloped particles by mixing with high concentrations of exogenous human bile salt (Hirai-Yuki et al. 2016). A noncancerous, polarized hepatocyte system that can support HEV replication and at the same time apically release bile salts would be ideal, as HepG2 cells are deficient in bile salt synthesis (Everson and Polokoff 1986).
PHH can be grown as sandwich cultures, which allows them to retain their hepatocyte polarization (Fig. 2A); however, in this configuration, the apical membrane and cargo is not accessible because of the closed bile canaliculi. Some evidence suggests that hepatocyte differentiation involves columnar intermediates (Treyer and Musch 2013). Therefore, a significant advance will be achieved if hESC/iPSCs can be differentiated on transwells to generate columnar polarized HLCs (Fig. 2B). Similar to polarized HepG2 cells, this system would enable studies of HEV vectorial release to delineate the differential trafficking routes of HEV to apical and basolateral cell surfaces. It will further allow studies on the role of bile salts in the maturation of virus particles. This system could be also used to determine whether HEV spreads to the neighboring cells through their apical surfaces, which may occur in the proximity of the bile canaliculi in vivo. The comparison with noncancerous polarized intestinal epithelial cells such as hESC/iPSC- or adult stem cell-derived intestinal organoids (reviewed in Fatehullah et al. 2016) would also be highly desirable. In contrast to hepatocytes, the virus is believed to bud primarily from intestinal cells through their 
V.L. Dao Thi et al.

basal membrane to reach the sinusoidal bloodstream and eventually the liver. Yet, similar to HAV, HEV particles bud from HEV-replicating Caco-2 cells primarily from the apical membrane (Emerson et al. 2010). Therefore, more physiologically relevant cellular systems will likely enable an improved and comprehensive modeling of enteric transmission pathways of viruses such as HAV and HEV.

The possibility to differentiate stem cells to HLCs in transwells or other micropatterned configurations (Berger et al. 2015) will allow cocultures with other stem cell-derived liver resident cell types and pave the way for the development of complex isogenic systems that better model the liver environment. This will enable improved drug development and drug-drug interaction predictions, especially for patients who have already progressed to severe liver disease and who have only limited treatment options.

\section{CONCLUDING REMARKS}

Despite the increasing awareness that hepatitis $\mathrm{E}$ is an important public health issue, HEV remains an understudied virus. The recent development of infectious clones has opened up new avenues for HEV studies in cell culture. However, basic life cycle steps, from HEV cell entry, over genome replication to particle assembly and release, remain poorly characterized. A pan-genotype, comprehensive characterization of the HEV replicase, including its subcellular localization and cellular cofactors, will likely be necessary for a better understanding of HEV host and tissue tropism as well as for the development of specific anti-HEV therapies. Stem cells providing renewable, genetically tractable, and noncancerous cellular systems hold the promise for advancing these studies. These systems may also aid in answering other fundamental questions, such as the identification of the HEV cell entry receptor(s) and its interaction with naked versus quasi-enveloped particles, genotype-dependent innate immune induction or evasion, which may be at play for the development of chronic hepatitis E, extrahepatic HEV replication and its clinical manifestations, and the role of insertions into the ORF1 hypervari- able region (HVR), which facilitate replication in hepatoma cells. In addition, the capability to study replication of nonadapted HEV isolates in tandem with autologous, patient-derived iPSCs further enables personalized models of HEV infection. The use of stem cell-derived culture models for studying HEV biology will lead to a better understanding of virus-host interactions and disease pathogenesis and may help develop novel, specific treatments.

\section{ACKNOWLEDGMENTS}

We thank Mohsan Saeed, Joseph M. Luna, and Eike Steinmann for critical reading of the manuscript. We apologize to colleagues whose work was not referenced because of space constraints.

\section{REFERENCES}

${ }^{*}$ Reference is also in this collection.

Agrawal S, Gupta D, Panda SK. 2001. The 3' end of hepatitis E virus (HEV) genome binds specifically to the viral RNA-dependent RNA polymerase (RdRp). Virology 282: $87-101$

Allweiss L, Gass S, Giersch K, Groth A, Kah J, Volz T, Rapp G, Schobel A, Lohse AW, Polywka S, et al. 2016. Human liver chimeric mice as a new model of chronic hepatitis $\mathrm{E}$ virus infection and preclinical drug evaluation. J Hepatol 64: 1033-1040.

Ansari IH, Nanda SK, Durgapal H, Agarawal S, Mohanty SK, Gupta D, Jameel S, Panda SK. 2000. Cloning, sequencing, and expression of the hepatitis $\mathrm{E}$ virus (HEV) nonstructural open reading frame 1 (ORF1). J Med Virol 60: 275 283.

Belouzard S, Danneels A, Feneant L, Seron K, Rouille Y, Dubuisson J. 2017. Entry and release of hepatitis C virus in polarized human hepatocytes. J Virol doi: 10.1125/ JVI.00478-17.

Berger DR, Ware BR, Davidson MD, Allsup SR, Khetani SR. 2015. Enhancing the functional maturity of induced pluripotent stem cell-derived human hepatocytes by controlled presentation of cell-cell interactions in vitro. Hepatology 61: 1370-1381.

Bhat P, Snooks MJ, Anderson DA. 2011. Hepatocytes traffic and export hepatitis B virus basolaterally by polarity-dependent mechanisms. J Virol 85: 12474-12481.

Blank CA, Anderson DA, Beard M, Lemon SM. 2000. Infection of polarized cultures of human intestinal epithelial cells with hepatitis A virus: Vectorial release of progeny virions through apical cellular membranes. J Virol 74: 6476-6484.

Bukh J, Pietschmann T, Lohmann V, Krieger N, Faulk K, Engle RE, Govindarajan S, Shapiro M, Claire MS, Bartenschlager R. 2002. Mutations that permit efficient replication of hepatitis C virus RNA in Huh-7 cells prevent 
productive replication in chimpanzees. Proc Natl Acad Sci 99: 14416-14421.

Carpentier A, Tesfaye A, Chu V, Nimgaonkar I, Zhang F, Lee SB, Thorgeirsson SS, Feinstone SM, Liang TJ. 2014. Engrafted human stem cell-derived hepatocytes establish an infectious HCV murine model. J Clin Invest 124: 49534964.

Casanova JL. 2015. Human genetic basis of interindividual variability in the course of infection. Proc Natl Acad Sci 112: E7118-E7127.

Chapuy-Regaud S, Dubois M, Plisson-Chastang C, Bonnefois T, Lhomme S, Bertrand-Michel J, You B, Simoneau S, Gleizes PE, Flan B, et al. 2017. Characterization of the lipid envelope of exosome encapsulated HEV particles protected from the immune response. Biochimie 141: 70-79.

Dalton HR, Kamar N. 2016. Treatment of hepatitis E virus. Curr Opin Infect Dis 29: 639-644.

Dao Thi VL, Debing Y, Wu X, Rice CM, Neyts J, Moradpour D, Gouttenoire J. 2016. Sofosbuvir inhibits hepatitis E virus replication in vitro and results in an additive effect when combined with ribavirin. Gastroenterology 150: 8285.e84.

Debing Y, Emerson SU, Wang Y, Pan Q, Balzarini J, Dallmeier K, Neyts J. 2014. Ribavirin inhibits in vitro hepatitis E virus replication through depletion of cellular GTP pools and is moderately synergistic with $\alpha$ interferon. Antimicrob Agents Chemother 58: 267-273.

Debing Y, Ramiere C, Dallmeier K, Piorkowski G, Trabaud MA, Lebosse F, Scholtes C, Roche M, Legras-Lachuer C, de Lamballerie X, et al. 2016. Hepatitis E virus mutations associated with ribavirin treatment failure result in altered viral fitness and ribavirin sensitivity. J Hepatol 65: 499508.

de Oya NJ, Escribano-Romero E, Blazquez AB, Lorenzo M, Martin-Acebes MA, Blasco R, Saiz JC. 2012. Characterization of hepatitis $\mathrm{E}$ virus recombinant ORF2 proteins expressed by vaccinia viruses. J Virol 86: 7880-7886.

Ding Q, Heller B, Capuccino JMV, Song BK, Nimgaonkar I, Hrebikova G, Contreras JE, Ploss A. 2017. Hepatitis E virus ORF3 is a functional ion channel required for release of infectious particles. Proc Natl Acad Sci 114: E4897E4897.

Dong C, Zafrullah M, Mixson-Hayden T, Dai X, Liang J, Meng J, Kamili S. 2012. Suppression of interferon- $\alpha$ signaling by hepatitis E virus. Hepatology 55: 1324-1332.

Drave SA, Debing Y, Walter S, Todt D, Engelmann M, Friesland M, Wedemeyer H, Neyts J, Behrendt P, Steinmann E. 2016. Extra-hepatic replication and infection of hepatitis E virus in neuronal-derived cells. J Viral Hepat 23: 512521.

Elaut G, Henkens T, Papeleu P, Snykers S, Vinken M, Vanhaecke T, Rogiers V. 2006. Molecular mechanisms underlying the dedifferentiation process of isolated hepatocytes and their cultures. Curr Drug Metab 7: 629-660.

Emerson SU, McRill C, Rosenblum B, Feinstone S, Purcell RH. 1991. Mutations responsible for adaptation of hepatitis A virus to efficient growth in cell culture. J Virol 65: 4882-4886.

Emerson SU, Nguyen HT, Torian U, Burke D, Engle R, Purcell RH. 2010. Release of genotype 1 hepatitis E virus from cultured hepatoma and polarized intestinal cells depends on open reading frame 3 protein and requires an intact PXXP motif. J Virol 84: 9059-9069.

Emerson SU, Nguyen HT, Torian U, Mather K, Firth AE. 2013. An essential RNA element resides in a central region of hepatitis E virus ORF2. J Gen Virol 94: 1468-1476.

Everson GT, Polokoff MA. 1986. Hepg2-A human hepatoblastoma cell-line exhibiting defects in bile-acid synthesis and conjugation. J Biol Chem 261: 2197-2201.

Fatehullah A, Tan SH, Barker N. 2016. Organoids as an in vitro model of human development and disease. Nat Cell Biol 18: 246-254.

Feng Z, Hensley L, McKnight KL, Hu F, Madden V, Ping L, Jeong SH, Walker C, Lanford RE, Lemon SM. 2013. A pathogenic picornavirus acquires an envelope by hijacking cellular membranes. Nature 496: 367-371.

Feng Z, Hirai-Yuki A, McKnight KL, Lemon SM. 2014. Naked viruses that aren't always naked: Quasi-enveloped agents of acute hepatitis. Ann Rev Virol 1: 539-560.

Funkhouser AW, Raychaudhuri G, Purcell RH, Govindarajan S, Elkins R, Emerson SU. 1996. Progress toward the development of a genetically engineered attenuated hepatitis a virus vaccine. J Virol 70: 7948-7957.

Graff J, Zhou YH, Torian U, Nguyen H, Claire MS, Yu C, Purcell RH, Emerson SU. 2008. Mutations within potential glycosylation sites in the capsid protein of hepatitis $\mathrm{E}$ virus prevent the formation of infectious virus particles. $J$ Virol 82: 1185-1194.

Harak C, Meyrath M, Romero-Brey I, Schenk C, Gondeau C, Schult P, Esser-Nobis K, Saeed M, Neddermann P, Schnitzler P, et al. 2017. Tuning a cellular lipid kinase activity adapts hepatitis $\mathrm{C}$ virus to replication in cell culture. Nat Microbiol 2: 17012.

Hartl J, Wehmeyer MH, Pischke S. 2016. Acute hepatitis E: Two sides of the same coin. Viruses 8: E299.

Helsen N, Debing Y, Paeshuyse J, Dallmeier K, Boon R, Coll M, Sancho-Bru P, Claes C, Neyts J, Verfaillie CM. 2016. Stem cell-derived hepatocytes: A novel model for hepatitis E virus replication. J Hepatol 64: 565-573.

Hirai-Yuki A, Hensley L, Whitmire JK, Lemon SM. 2016. Biliary secretion of quasi-enveloped human hepatitis A virus. Mbio 7: 01998.

Jameel S, Zafrullah M, Ozdener MH, Panda SK. 1996. Expression in animal cells and characterization of the hepatitis E virus structural proteins. J Virol 70: 207-216.

Johne R, Reetz J, Ulrich RG, Machnowska P, Sachsenroder J, Nickel P, Hofmann J. 2014. An ORF1-rearranged hepatitis $\mathrm{E}$ virus derived from a chronically infected patient efficiently replicates in cell culture. J Viral Hepat 21: $447-456$.

Kamar N, Dalton HR, Abravanel F, Izopet J. 2014. Hepatitis E virus infection. Clin Microbiol Rev 27: 116-138.

Kamar N, Lhomme S, Abravanel F, Cointault O, Esposito L, Cardeau-Desangles I, Del Bello A, Dorr G, Lavayssiere L, Nogier MB, et al. 2015. An early viral response predicts the virological response to ribavirin in hepatitis $\mathrm{E}$ virus organ transplant patients. Transplantation 99: 21242131.

Kaneko S, Kakinuma S, Asahina Y, Kamiya A, Miyoshi M, Tsunoda T, Nitta S, Asano Y, Nagata H, Otani S, et al. 2016. Human induced pluripotent stem cell-derived 
V.L. Dao Thi et al.

hepatic cell lines as a new model for host interaction with hepatitis B virus. Sci Rep 6: 29358.

Karpe YA, Lole KS. 2010. NTPase and 5' to 3' RNA duplexunwinding activities of the hepatitis $\mathrm{E}$ virus helicase domain. J Virol 84: 3595-3602.

Kenney SP, Meng XJ. 2015. The lysine residues within the human ribosomal protein S17 sequence naturally inserted into the viral nonstructural protein of a unique strain of hepatitis $\mathrm{E}$ virus are important for enhanced virus replication. J Virol 89: 3793-3803.

* Kenney SP, Meng X-J. 2018. Hepatitis E virus genome structure and replication strategy. Cold Spring Harb Perspect Med doi: 10.1101/cshperspect.a031724.

Kenney SP, Wentworth JL, Heffron CL, Meng XJ. 2015. Replacement of the hepatitis E virus ORF3 protein PxxP motif with heterologous late domain motifs affects virus release via interaction with TSG101. Virology 486: 198208.

Khetani SR, Bhatia SN. 2008. Microscale culture of human liver cells for drug development. Nat Biotechnol 26: 120 126.

Lee GH, Tan BH, Chi-Yuan Teo E, Lim SG, Dan YY, Wee A Aw PP, Zhu Y, Hibberd ML, Tan CK, et al. 2016. Chronic infection with camelid hepatitis $\mathrm{E}$ virus in a liver transplant recipient who regularly consumes camel meat and milk. Gastroenterology 150: 355-357.e3.

Lenggenhager D, Gouttenoire J, Malehmir M, Bawohl M, Honcharova-Biletska H, Kreutzer S, Semela D, Neuweiler J, Hurlimann S, Aepli P, et al. 2017. Visualization of hepatitis $\mathrm{E}$ virus RNA and proteins in the human liver. $J$ Hepatol 67: 471-479.

Lhomme S, Abravanel F, Dubois M, Sandres-Saune K, Rostaing L, Kamar N, Izopet J. 2012. Hepatitis E virus quasispecies and the outcome of acute hepatitis E in solidorgan transplant patients. J Virol 86: 10006-10014.

Liu P, Bu QN, Wang L, Han J, Du RJ, Lei YX, Ouyang YQ, L J, Zhu YH, Lu FM, et al. 2013. Transmission of hepatitis E virus from rabbits to cynomolgus macaques. Emerg Infect Dis 19: 559-565.

Liu W, Li J, Zheng WN, Shang YL, Zhao ZD, Wang SS, Bi YH, Zhang S, Xu CF, Duan ZY, et al. 2017. Cyclophilin Aregulated ubiquitination is critical for RIG-I-mediated antiviral immune responses. eLife 6: e24425.

Lohmann V, Korner F, Dobierzewska A, Bartenschlager R 2001. Mutations in hepatitis C virus RNAs conferring cell culture adaptation. J Virol 75: 1437-1449.

Magden J, Takeda N, Li T, Auvinen P, Ahola T, Miyamura T, Merits A, Kaariainen L. 2001. Virus-specific mRNA capping enzyme encoded by hepatitis E virus. $J$ Virol 75: 6249-6255.

Musch A. 2014. The unique polarity phenotype of hepatocytes. Exp Cell Res 328: 276-283.

Nagashima S, Takahashi M, Jirintai S, Tanaka T, Yamada K, Nishizawa T, Okamoto H. 2011. A PSAP motif in the ORF3 protein of hepatitis $\mathrm{E}$ virus is necessary for virion release from infected cells. J Gen Virol 92: 269-278.

Nagashima S, Takahashi M, Jirintai S, Tanggis B, Kobayashi T, Nishizawa T, Okamoto H. 2014. The membrane on the surface of hepatitis $\mathrm{E}$ virus particles is derived from the intracellular membrane and contains trans-Golgi network protein 2. Arch Virol 159: 979-991.
Nair VP, Anang S, Subramani C, Madhvi A, Bakshi K, Srivastava A, Shalimar, Nayak B, Ct RK, Surjit M. 2016. Endoplasmic reticulum stress induced synthesis of a novel viral factor mediates efficient replication of genotype-1 hepatitis E virus. PLoS Pathog 12: e1005521.

Nan Y, Yu Y, Ma Z, Khattar SK, Fredericksen B, Zhang YJ. 2014. Hepatitis $E$ virus inhibits type I interferon induction by ORF1 products. J Virol 88: 11924-11932.

Navaneethan U, Al Mohajer M, Shata MT. 2008. Hepatitis E and pregnancy: Understanding the pathogenesis. Liver Int 28: 1190-1199.

Nguyen HT, Torian U, Faulk K, Mather K, Engle RE, Thompson E, Bonkovsky HL, Emerson SU. 2012. A naturally occurring human/hepatitis $\mathrm{E}$ recombinant virus predominates in serum but not in faeces of a chronic hepatitis $\mathrm{E}$ patient and has a growth advantage in cell culture. J Gen Virol 93: 526-530.

Nguyen HT, Shukla P, Torian U, Faulk K, Emerson SU. 2014. Hepatitis E virus genotype 1 infection of swine kidney cells in vitro is inhibited at multiple levels. $J$ Virol 88: 868-877.

Ni Y, Lempp FA, Mehrle S, Nkongolo S, Kaufman C, Falth M, Stindt J, Koniger C, Nassal M, Kubitz R, et al. 2014. Hepatitis B and D viruses exploit sodium taurocholate cotransporting polypeptide for species-specific entry into hepatocytes. Gastroenterology 146: 1070-1083.

Okamoto H. 2011. Hepatitis E virus cell culture models. Virus Res 161: 65-77.

Osterman A, Stellberger T, Gebhardt A, Kurz M, Friedel CC, Uetz P, Nitschko H, Baiker A, Vizoso-Pinto MG. 2015. The hepatitis E virus intraviral interactome. Sci Rep 5: 13872.

Paganelli M, Dallmeier K, Nyabi O, Scheers I, Kabamba B, Neyts J, Goubau P, Najimi M, Sokal EM. 2013. Differentiated umbilical cord matrix stem cells as a new in vitro model to study early events during hepatitis B virus infection. Hepatology 57: 59-69.

Perttila J, Spuul P, Ahola T. 2013. Early secretory pathway localization and lack of processing for hepatitis $\mathrm{E}$ virus replication protein pORF1. J Gen Virol 94: 807-816.

Pollin TI. 2009. A null mutation in human APOC3 confers a favorable plasma lipid profile and apparent cardioprotection. Science 323: 583-583.

Qi Y, Zhang F, Zhang L, Harrison TJ, Huang WJ, Zhao CY, Kong W, Jiang CL, Wang YC. 2015. Hepatitis E virus produced from cell culture has a lipid envelope. PLoS ONE 10: $\mathrm{e} 0132503$.

Renou C, Gobert V, Locher C, Moumen A, Timbely O, Savary J, Roque-Afonso AM; Association Nationale des Hépato-Gastroénterologues des Hôpitaux Génréaux (ANGH). 2014. Prospective study of hepatitis E virus infection among pregnant women in France. Virol J 11: 68.

Roelandt P, Obeid S, Paeshuyse J, Vanhove J, Van Lommel A, Nahmias Y, Nevens F, Neyts J, Verfaillie CM. 2012. Human pluripotent stem cell-derived hepatocytes support complete replication of hepatitis C virus. J Hepatol 57: 246-251.

Rogee S, Le Gall M, Chafey P, Bouquet J, Cordonnier N, Frederici C, Pavio N. 2015. Quantitative proteomics identifies host factors modulated during acute hepatitis $\mathrm{E}$ virus infection in the swine model. J Virol 89: 129-143. 
Ropp SL, Tam AW, Beames B, Purdy M, Frey TK. 2000 Expression of the hepatitis E virus ORF1. Arch Virol 145: 1321-1337.

Roy AK, Korkaya H, Oberoi R, Lal SK, Jameel S. 2004. The hepatitis $\mathrm{E}$ virus open reading frame 3 protein activates ERK through binding and inhibition of the MAPK phosphatase. J Biol Chem 279: 28345-28357.

Saeed M, Andreo U, Chung HY, Espiritu C, Branch AD, Silva JM, Rice CM. 2015. SEC14L2 enables pan-genotype HCV replication in cell culture. Nature 524: 471-475.

Sayed IM, Verhoye L, Cocquerel L, Abravanel F, Foquet L, Montpellier C, Debing Y, Farhoudi A, Wychowski C, Dubuisson J, et al. 2017. Study of hepatitis E virus infection of genotype 1 and 3 in mice with humanised liver. Gut 66: 920-929.

Schwartz RE, Trehan K, Andrus L, Sheahan TP, Ploss A, Duncan SA, Rice CM, Bhatia SN. 2012. Modeling hepatitis $C$ virus infection using human induced pluripotent stem cells. Proc Natl Acad Sci 109: 2544-2548.

Schwartz RE, Fleming HE, Khetani SR, Bhatia SN. 2014 Pluripotent stem cell-derived hepatocyte-like cells. Biotechnol Adv 32: 504-513.

Shlomai A, Schwartz RE, Ramanan V, Bhatta A, de Jong YP, Bhatia SN, Rice CM. 2014. Modeling host interactions with hepatitis B virus using primary and induced pluripotent stem cell-derived hepatocellular systems. Proc Natl Acad Sci 111: 12193-12198.

Shukla P, Nguyen HT, Torian U, Engle RE, Faulk K, Dalton HR, Bendall RP, Keane FE, Purcell RH, Emerson SU. 2011. Cross-species infections of cultured cells by hepatitis $\mathrm{E}$ virus and discovery of an infectious virus-host recombinant. Proc Natl Acad Sci 108: 2438-2443.

Shukla P, Nguyen HT, Faulk K, Mather K, Torian U, Engle RE, Emerson SU. 2012. Adaptation of a genotype 3 hepatitis $\mathrm{E}$ virus to efficient growth in cell culture depends on an inserted human gene segment acquired by recombination. J Virol 86: 5697-5707.

Snooks MJ, Bhat P, Mackenzie J, Counihan NA, Vaughan N, Anderson DA. 2008. Vectorial entry and release of hepatitis A virus in polarized human hepatocytes. J Virol 82: 8733-8742.

Sooryanarain H, Rogers AJ, Cao DJ, Haac MER, Karpe YA, Meng XJ. 2017. ISG15 modulates type I Interferon signaling and the antiviral response during hepatitis $\mathrm{E}$ virus replication. J Virol 91: e00621.

Suppiah S, Zhou YM, Frey TK. 2011. Lack of processing of the expressed ORF1 gene product of hepatitis $\mathrm{E}$ virus. Virol J 8: 245.

Surjit M, Jameel S, Lal SK. 2004. The ORF2 protein of hepatitis $\mathrm{E}$ virus binds the $5^{\prime}$ region of viral RNA. J Virol 78 320-328.

Surjit M, Jameel S, Lal SK. 2007. Cytoplasmic localization of the ORF2 protein of hepatitis $\mathrm{E}$ virus is dependent on its ability to undergo retrotranslocation from the endoplasmic reticulum. J Virol 81: 3339-3345.

Takahashi K, Tanabe K, Ohnuki M, Narita M, Ichisaka T, Tomoda K, Yamanaka S. 2007. Induction of pluripotent stem cells from adult human fibroblasts by defined factors. Cell 131: 861-872.

Takahashi M, Tanaka T, Takahashi H, Hoshino Y, Nagashima S, Jirintai S, Mizuo H, Yazaki Y, Takagi T, Azuma
M, et al. 2010. Hepatitis E virus (HEV) strains in serum samples can replicate efficiently in cultured cells despite the coexistence of HEV antibodies: Characterization of HEV virions in blood circulation. J Clin Microbiol 48: 1112-1125.

Tanaka T, Takahashi M, Kusano E, Okamoto H. 2007. Development and evaluation of an efficient cell-culture system for hepatitis E virus. J Gen Virol 88: 903-911.

Tanaka T, Takahashi M, Takahashi H, Ichiyama K, Hoshino Y, Nagashima S, Mizuo H, Okamoto H. 2009. Development and characterization of a genotype 4 hepatitis $\mathrm{E}$ virus cell culture system using a HE-JF5/15F strain recovered from a fulminant hepatitis patient. J Clin Microbiol 47: 1906-1910.

Tian YB, Huang WJ, Yang J, Wen ZH, Geng YS, Zhao CY, Zhang HQ, Wang YC. 2017. Systematic identification of hepatitis $\mathrm{E}$ virus ORF2 interactome reveals that TMEM134 engages in ORF2-mediated NF- $\kappa \mathrm{B}$ pathway. Virus Res 228: 102-108.

Todt D, Francois C, Anggakusuma, Behrendt P, Engelmann M, Knegendorf L, Vieyres G, Wedemeyer H, Hartmann R, Pietschmann T, et al. 2016a. Antiviral activities of different interferon types and subtypes against hepatitis $\mathrm{E}$ virus replication. Antimicrob Agents Chemother 60: 2132 2139.

Todt D, Gisa A, Radonic A, Nitsche A, Behrendt P, Suneetha PV, Pischke S, Bremer B, Brown RJ, Manns MP, et al. 2016b. In vivo evidence for ribavirin-induced mutagenesis of the hepatitis E virus genome. Gut 65: 17331743.

Torresi J, Li F, Locarnini SA, Anderson DA. 1999. Only the non-glycosylated fraction of hepatitis $\mathrm{E}$ virus capsid (open reading frame 2) protein is stable in mammalian cells. J Gen Virol 80: 1185-1188.

Treyer A, Musch A. 2013. Hepatocyte polarity. Compr Physiol 3: 243-287.

Tyagi S, Jameel S, Lal SK. 2001. Self-association and mapping of the interaction domain of hepatitis $\mathrm{E}$ virus ORF3 protein. J Virol 75: 2493-2498.

van Tong H, Hoan NX, Wang B, Wedemeyer H, Bock CT, Velavan TP. 2016. Hepatitis E virus mutations: Functional and clinical relevance. EBioMedicine 11: 31-42.

Wang Y, Zhou X, Debing Y, Chen K, Van Der Laan LJ, Neyts J, Janssen HL, Metselaar HJ, Peppelenbosch MP, Pan Q. 2014. Calcineurin inhibitors stimulate and mycophenolic acid inhibits replication of hepatitis E virus. Gastroenterology 146: 1775-1783.

Weller R, Todt D, Engelmann M, Friesland M, Wedemeyer H, Pietschmann T, Steinmann E. 2016. Apolipoprotein E polymorphisms and their protective effect on hepatitis $\mathrm{E}$ virus replication. Hepatology 64: 2274-2276.

Williams TPE, Kasorndorkbua C, Halbur PG, Haqshenas G, Guenette DK, Toth TE, Meng XJ. 2001. Evidence of extrahepatic sites of replication of the hepatitis $\mathrm{E}$ virus in a swine model. J Clin Microbiol 39: 3040-3046.

Wu X, Robotham JM, Lee E, Dalton S, Kneteman NM, Gilbert DM, Tang H. 2012. Productive hepatitis $C$ virus infection of stem cell-derived hepatocytes reveals a critical transition to viral permissiveness during differentiation. PLoS Pathog 8: e1002617.

Wu X, Dao Thi VL, Liu P, Takacs CN, Xiang K, Andrus L, Gouttenoire J, Moradpour D, Rice CM. 2017. Pan-geno- 
V.L. Dao Thi et al.

type hepatitis E virus replication in stem cell-derived hepatocellular systems. Gastroenterology doi: 10.1053/j.gastro.2017.10.041.

Xia Y, Carpentier A, Cheng XM, Block PD, Zhao Y, Zhang ZS, Protzer U, Liang TJ. 2017. Human stem cell-derived hepatocytes as a model for hepatitis B virus infection, spreading and virus-host interactions. J Hepatol 66: 494-503.

Xing L, Li TC, Mayazaki N, Simon MN, Wall JS, Moore M, Wang CY, Takeda N, Wakita T, Miyamura T, et al. 2010 Structure of hepatitis $\mathrm{E}$ virion-sized particle reveals an RNA-dependent viral assembly pathway. J Biol Chem 285: 33175-33183.

Yamada K, Takahashi M, Hoshino Y, Takahashi H, Ichiyama K, Nagashima S, Tanaka T, Okamoto H. 2009. ORF3 protein of hepatitis $\mathrm{E}$ virus is essential for virion release from infected cells. J Gen Virol 90: 1880-1891.

Yan H, Zhong G, Xu G, He W, Jing Z, Gao Z, Huang Y, Qi Y, Peng B, Wang H, et al. 2012. Sodium taurocholate cotransporting polypeptide is a functional receptor for human hepatitis $\mathrm{B}$ and $\mathrm{D}$ virus. eLife 1: e00049.

Yang F, Robotham JM, Grise H, Frausto S, Madan V, Zayas M, Bartenschlager R, Robinson M, Greenstein AE, Nag A, et al. 2010. A major determinant of cyclophilin dependence and cyclosporine susceptibility of hepatitis C virus identified by a genetic approach. PLoS Pathog 6: e1001118.
Yin X, Ambardekar C, Lu Y, Feng Z. 2016. Distinct entry mechanisms for nonenveloped and quasi-enveloped hepatitis E viruses. J Virol 90: 4232-4242.

Yin X, Ambardekar C, Hu Z, Lhomme S, Feng Z. 2017. Hepatitis $\mathrm{E}$ virus persists in the presence of a type III interferon response. PLoS Pathog 13: e1006417.

Yoshida T, Takayama K, Kondoh M, Sakurai F, Tani H, Sakamoto N, Matsuura Y, Mizuguchi H, Yagi K. 2011. Use of human hepatocyte-like cells derived from induced pluripotent stem cells as a model for hepatocytes in hepatitis C virus infection. Biochem Biophys Res Commun 416: 119-124.

Zafrullah M, Ozdener MH, Kumar R, Panda SK, Jameel S. 1999. Mutational analysis of glycosylation, membrane translocation, and cell surface expression of the hepatitis E virus ORF2 protein. J Virol 73: 4074-4082.

Zhang L, Yesupriya A, Chang MH, Teshale E, Teo CG. 2015 Apolipoprotein E and protection against hepatitis E viral infection in American non-Hispanic blacks. Hepatology 62: 1346-1352.

Zhou XY, Wang YJ, Metselaar HJ, Janssen HLA, Peppelenbosch MP, Pan QW. 2014. Rapamycin and everolimus facilitate hepatitis E virus replication: Revealing a basa defense mechanism of PI3K-PKB-mTOR pathway. J Hepatol 61: 746-754.

Zhou X, Huang F, Xu L, Lin ZM, de Vrij FMS, Ayo-Martin AC, van der Kroeg M, Zhao MZ, Yin YB, Wang WS, et al 2017. Hepatitis $E$ virus infects neurons and brains. J Infect Dis 215: 1197-1206. 


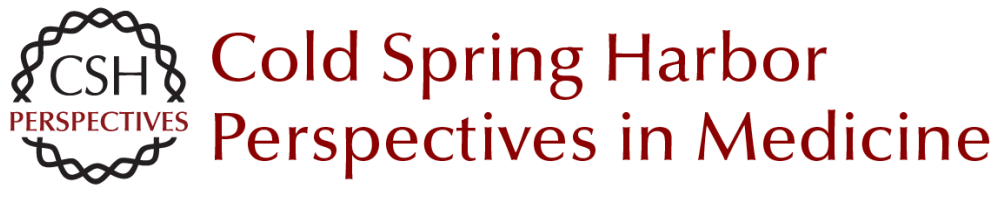

\section{Stem Cell-Derived Culture Models of Hepatitis E Virus Infection}

Viet Loan Dao Thi, Xianfang Wu and Charles M. Rice

Cold Spring Harb Perspect Med 2019; doi: 10.1101/cshperspect.a031799 originally published online April 23, 2018

\section{Subject Collection Enteric Hepatitis Viruses}

Hepatitis A Virus Genome Organization and Replication Strategy

Kevin L. McKnight and Stanley M. Lemon

Adaptive Immune Responses in Hepatitis A Virus and Hepatitis E Virus Infections

Christopher M. Walker

Small Animal Models of Hepatitis E Virus Infection Tian-Cheng Li and Takaji Wakita

Acute and Persistent Hepatitis E Virus Genotype 3 and 4 Infection: Clinical Features, Pathogenesis, and Treatment

Nassim Kamar and Sven Pischke

Epidemiology of Genotype 1 and 2 Hepatitis E Virus Infections

Kenrad E. Nelson, Alain B. Labrique and Brittany L. Kmush

History of the Discovery of Hepatitis A Virus Stephen M. Feinstone

Epidemiology and Transmission of Hepatitis A Virus and Hepatitis E Virus Infections in the United States

Megan G. Hofmeister, Monique A. Foster and Eyasu H. Teshale

Stem Cell-Derived Culture Models of Hepatitis E Virus Infection

Viet Loan Dao Thi, Xianfang Wu and Charles M. Rice
Evolutionary Origins of Enteric Hepatitis Viruses Anna-Lena Sander, Victor Max Corman, Alexander N. Lukashev, et al.

Enterically Transmitted Non-A, Non-B Hepatitis and the Discovery of Hepatitis E Virus

Stanley M. Lemon and Christopher M. Walker

Natural History, Clinical Manifestations, and

Pathogenesis of Hepatitis E Virus Genotype 1 and

2 Infections

Rakesh Aggarwal and Amit Goel

Hepatitis A Virus and Hepatitis E Virus: Emerging and Re-Emerging Enterically Transmitted

Hepatitis Viruses

Stanley M. Lemon and Christopher M. Walker

Hepatitis A Virus Capsid Structure

David I. Stuart, Jingshan Ren, Xiangxi Wang, et al.

Comparative Pathology of Hepatitis A Virus and Hepatitis E Virus Infection John M. Cullen and Stanley M. Lemon

Innate Immunity to Enteric Hepatitis Viruses Zongdi Feng and Stanley M. Lemon

Nonhuman Primate Models of Hepatitis A Virus and Hepatitis E Virus Infections

Robert E. Lanford, Christopher M. Walker and

Stanley M. Lemon

For additional articles in this collection, see http://perspectivesinmedicine.cshlp.org/cgi/collection/ 